\title{
Pengembangan Media Teka-Teki Silang (TTS) untuk Pembelajaran Tematik Kelas VI SD
}

\author{
Development of Cross Puzzles Media for the Thematic Learning for VI Grade of \\ Elementary School \\ ${ }^{1}$ Darinah, ${ }^{2}$ Sukirno \\ ${ }^{1)}$ SDN 1 Purwanegara \\ ${ }^{2)}$ Universitas Muhammadiyah Purwokerto \\ *email: darinahmukhayat@gmail.com, sukirnopwt56@gmail.com
}

\begin{abstract}
Histori Artikel:
ABSTRAK

Diajukan:

$14 / 10 / 2021$

Diterima:

09/11/2021

Diterbitkan:

$08 / 12 / 2021$

Penelitian ini bertujuan untuk mengembangkan media pembelajaran TTS pada pembelajaran tematik di kelas VI SD. Penelitian ini merupakan Research and Development $(R \& D)$. Penelitian ini dilakukan di Gugus Untung Suropati, Sampel dalam penelitian ini dipilih secara cluster random sampling dari keseluruhan populasi adalah 11 kelas yang dijadikan kelas eksperimen dan kelas kontrol. Hasil penelitian menunjukkan bahwa: (1) Tahap penyusunan dan pengembangan media TTS ditempuh melalui 3 tahapan, yaitu menganalisis kebutuhan guru, menganalisis kebutuhan siswa, dan mengembangkan media TTS sebagai media pembelajaran tematik di kelas VI SD, (2) Validitas media TTS dinyatakan valid melalui penilaian dari hasil validasi ahli I dan II, saran dan masukan yang baik untuk dikembang-kannya produk media, serta respon pengguna media TTS. Dari hasil analisis validator diperoleh rata-rata presentase berturut-turut sebesar $78 \%$ dan 74,34\%, dalam kategori sangat baik dan layak digunakan dalam kegiatan pembelajaran tematik kelas VI SD, dan (3) Tingkat keefektifan media TTS pada pembelajaran tematik dapat diketahui dari hasil uji coba produk yang menunjukkan bahwa hasil belajar pada kelas eksperimen yang menggunakan media TTS pada materi tema 9 pembelajaran tematik lebih baik daripada kelas kontrol yang menggunakan pembelajaran konvensional (buku teks). Media TTS juga mendapat respon baik oleh peserta didik.
\end{abstract}

Kata kunci: Media, TTS, Tematik

\begin{abstract}
This study aims to develop TTS learning media in thematic learning in grade VI SD. This research is a Research and Development $(R \& D)$. This research was conducted in the Untung Suropati Cluster. The sample in this study was selected by cluster random sampling from the entire population, 11 classes were used as the experimental class and the control class. The results showed that: (1) The preparation and development of TTS media was carried out through 3 stages, namely analyzing teacher needs, analyzing student needs, and developing TTS media as thematic learning media in grade VI SD, (2) The validity of TTS media was declared valid through assessment of the results of the validation of experts I and II, good suggestions and input for the development of media products, as well as responses from TTS media users. From the results of the validator analysis, it was obtained that the average percentage was $78 \%$ and $74.34 \%$, in the very good category and suitable for use in the thematic learning activities of class VI SD, and (3) The effectiveness level of TTS media in thematic learning can be seen from the results of the product trial show that the learning outcomes in the experimental class using TTS media on theme 9 thematic learning materials are better than the control class using conventional learning (textbooks). TTS media also received a good response by students.
\end{abstract}

Keywords: Media, TTS, Thematic 


\section{PENDAHULUAN}

Kurikulum Tingkat Satuan Pendidikan tahun 2006, salah satu standar kompetensi membaca kelas IV SD adalah memahami teks dengan kompetensi dasar menemukan pokok pikiran dan menemukan kalimat utama pada tiap paragraf (Permendiknas No. 22 Tahun 2006). Kurikulum 2013 yang menerapkan pembelajaran tematik, pada materi pembelajarannya berbasis teks. Hal ini menuntut guru maupun siswa untuk memiliki banyak kosa kata yang dibutuhkan untuk memahami teks. Dengan berbekal pemahaman kosa kata yang banyak tentu akan dapat membantu siswa mencapai tujuan pembelajaran.

Peraturan tentang Gerakan Literasi Sekolah (GLS) yang diturunkan dari Permendikbud Nomor 23 Tahun 2015 tentang Penumbuhan Budi Pekerti, telah disosialisasikan oleh Pemerintah. Semua sekolah wajib melakukan kegiatan menggunakan waktu 15 menit sebelum pembelajaran untuk membaca buku selain buku mata pelajaran (setiap hari).

Kondisi peserta didik saat ini terhadap gerakan literasi khususnya membaca dan menulis masih sangat rendah. Perbendaharaan kata atau istilah yang dimiliki oleh peserta didik pun masih sangat terbatas. Guru dituntut untuk dapat memotivasi para peserta didiknya, dengan berkreatifitas dan berinovasi agar siswa memiliki kebiasaan gemar membaca dan menulis.

Dalam Suyatno (2005:3-4) disebutkan karakteristik siswa antara lain: (1) Dunia siswa adalah dunia bermain. Karena itu sebaiknya materi pelajaran banyak yang disajikan dengan melalui permainan; (2) Usia siswa merupakan usia yang paling kreatif dalam hidup manusia. Karena itulah seharusnya dunia pendidikan melalui guru mampu memberikan kesempatan bagi kreativitasnya untuk berkembang.

Dalam pandangan teori psikologi yang dipelopori B.F. Skinner (1904-1990) disebutkan bahwa semua perilaku dianggap sebagai respons terhadap stimuli. Semua proses belajar bersifat asosiatif, atau pembetulan kebiasaan (habit formation), yang diakibatkan oleh proses menghubungkan antara stimulus dan respon.

TTS merupakan salah satu permainan yang dapat dijadikan sebagai media pembelajaran dalam rangka mendukung proses pembelajaran agar lebih menarik dan menyenangkan. Permainan TTS dapat dikembangkan menjadi sebuah media yang menarik dan menyenangkan bagi siswa, sehingga semua siswa dapat terlibat secara aktif dalam permbelajaran, terasah otaknya sehingga banyak perbendaharaan kosa kata yang dapat diperoleh untuk memahami pengetahuan tertentu. Media TTS dapat dijadikan sebagai satu stimuli yang dapat membantu peserta didik belajar untuk menguasai kosa kata atau istilahistilah dalam pembelajaran tematik di sekolah dasar.

Berdasar hal tersebut di atas, penulis tertarik untuk melakukan penelitian lebih lanjut dengan judul "Pengembangan Media Teka-Teki Silang (TTS) untuk Pembelajaran Tematik Kelas VI SD".

Penulis merumuskan beberapa masalah sebagai berikut ini.

1. Bagaimanakah tahap penyusunan dan pengembangan media TTS pada pembelajaran tematik di kelas VI SD?

2. Bagaimanakah tingkat validitas media TTS pada pembelajaran tematik di kelas VI SD?

3. Bagaimanakah tingkat keefektifan media TTS pada pembelajaran tematik di kelas VI $\mathrm{SD}$ ?

Berdasar rumusan masalah tersebut, maka penelitian ini disusun dengan tujuan sebagai berikut:

1. untuk menghasilkan tahap penyusunan dan pengembangan media TTS pada pembelajaran tematik di kelas VI SD,

2. untuk mengetahui tingkat validitas media TTS pada pembelajaran tematik di kelas VI $\mathrm{SD}$,

3. untuk mengetahui tingkat keefektifan media TTS pada pembelajaran tematik di kelas VI SD. 
Beberapa penelitian yang relevan terkait dengan pengembangan teka-teki silang sebagai media pembelajaran antara lain :

1. Penelitian Mohammad Andi Wasgito dan Wayan Setiadarma yang berjudul "Pengembangan Media Permainan Edukatif TTS dalam Proses Pembelajaran Siswa Kelas VII SMP Negeri 2 Kalianget, menunjukkan hasil pengembangan media teka-teki silang dianggap telah memenuhi kelayakan ;

2. Penelitian lain yang telah dilakukan oleh Nur Ulfayanti yang berjudul 'Pengembangan Media Permainan Tekateki Silang pada Mata Pelajaran Biologi Kelas XI di SMA Negeri 12 Makasar" yang menyimpulkan bahwa media teka-teki silang yang dikembangkan menggunakan model 3D memenuhi kategori valid, praktis, dan efektif;

3. Penelitian Gusmita Ul Husna dan Hera Hastuti yang berjudul Pengembangan Media Teka Teki Silang sebagai Media Pembelajaran Sejarah di Kelas XI SMA, hasil dari penelitian ini menunjukkan bahwa Pengembangan Media TTS dapat membantu siswa dalam mengingat fakta dan konsep yang ada pada pembelajaran sejarah Indonesia.

4. Penelitian dari Yulia Elviza, dkk. yang berjudul 'Peningkatan Kosa Kata melalui Teknik Permainan Teka-Teki Silang di
Kelas VII.A SMP N 2 Sungai Penuh". Hasil Penelitian tersebut disimpulkan bahwa penerapan teknik permainan teka-teki silang dapat meningkatkan proses dan hasil pembelajaran kosakata di kelas VII A SMP Negeri 2 Sungai Penuh.

Berikut ini perbedaan penelitian yang penulis lakukan dengan penelitian-penelitian lain yang sudah penulis ulas di atas. Media TTS yang peneliti gunakan merupakan produk sendiri yang digunakan dalam pembelajaran tematik di kelas dengan meninggalkan pesan berupa kata-kata mutiara sebagai upaya penanaman pendidikan karakter bagi peserta didik. Biasanya media TTS digunakan pada mapel tertentu, sedangkan dalam pembelajaran tematik media TTS untuk beberapa mapel yang terhimpun dalam satu tema pembelajaran.

\section{METODE}

Penelitian dilakukan dengan menggunakan metode penelitian dan pengembangan (Research \& Development). Menurut Sugiyono (2015: 297) metode penelitian dan pengembangan atau dalam bahasa Inggrisnya Research and Development adalah metode penelitian yang digunakan untuk menghasilkan produk tertentu, dan menguji kefektifan produk tersebut.

Penelitian ini dilakukan dalam tujuh tahap penelitian. Tujuh tahap penelitian dijabarkan sebagai berikut:

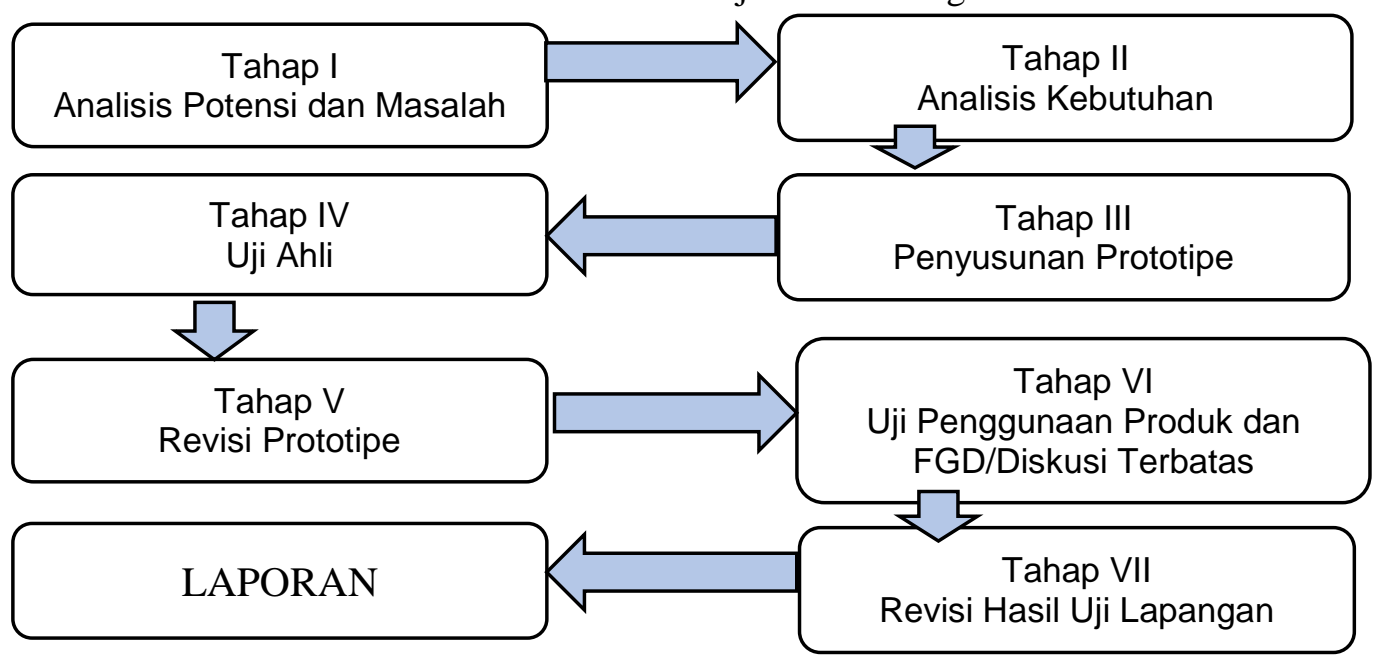

Gambar.3.1 Tahap Penggunaan Metode R\&D

Diadaptasi dari Blog and Goal (dalam Sugiyono 2015: 409) 
Populasi dalam penelitian ini adalah siswa kelas VI Sekolah Dasar (SD) di Gugus Untung Suropati, wilayah Korwilcam Dindik Purwokerto Utara yang tersebar di 11 Sekolah Dasar. Karena keterbatasan waktu, tenaga, maupun biaya, maka peneliti akan menggunakan sampel dalam penelitian dengan teknik cluster random sampling. Ada 11 SD yang ada di Gugus Untung Suropati Korwilcam Dindik Purwokerto Utara, yang datanya meliputi sebagai berikut:

Tabel. 3.1 Daftar SD N/S di Gugus Untung Suropati

\begin{tabular}{|c|c|c|}
\hline No & Nama Sekolah & $\begin{array}{c}\text { Jumlah } \\
\text { siswa kelas } \\
\text { VI }\end{array}$ \\
\hline 1 & SD N 1 Bancarkembar & 34 \\
\hline 2 & SD N 3 Bancarkembar & 33 \\
\hline 3 & SD N 4 Bancarkembar & 25 \\
\hline 4 & SD N 1 Purwanegara & 37 \\
\hline 5 & SD N 2 Purwanegara & 29 \\
\hline 6 & SD N 3 Purwanegara & 24 \\
\hline 7 & SD N 4 Purwanegara & 29 \\
\hline 8 & SD N 1 Bobosan & 47 \\
\hline 9 & SD N 2 Bobosan & 28 \\
\hline 10 & SD N 3 Bobosan & 18 \\
\hline 11 & SD Muhammadiyah & 43 \\
\hline \multicolumn{2}{|c|}{ Purwokerto } & $\mathbf{3 4 7}$ \\
\hline
\end{tabular}

Teknik Cluster random Sampling adalah teknik pengambilan sampel dimana pemilihannya mengacu pada kelompok bukan pada individu (Sugiyono, 2015). Cara seperti ini dinilai paling sesuai untuk dilakukan pada populasi yang kerangka sampelnya sudah ada seperti pada peserta didik di sekolah yang sudah dibagi pada tiap kelas (Sugiyono, 2014). Teknik cluster random sampling digunakan untuk memilih sampel penelitian yang terdiri dari kelas penelitian dan bukan kelas penelitian. Sebelum pemilihan sampel dilakukan uji normalitas dan uji homogenitas sebagai data awal dengan menggunakan nilai yang sudah ada. Berdasarkan uji normalitas dan homogenitas data 7 kelas diperoleh data sebagai berikut.

Tabel 3.2 Hasil Uji Normalitas dan Homogenitas

Penentuan Sampel Penelitian

\begin{tabular}{ccccccc}
\hline Kelas & $\mathrm{n}_{\mathrm{i}}$ & $\begin{array}{c}\mathrm{dk}= \\
\mathrm{n}_{\mathrm{i}}-1\end{array}$ & $\mathrm{Si}^{2}$ & $(\mathrm{dk}) \mathrm{S}_{\mathrm{i}}^{2}$ & $\log \mathrm{S}_{\mathrm{i}}{ }^{2}$ & $\begin{array}{c}(\mathrm{dk}) \log \\
\mathrm{S}_{\mathrm{i}}{ }^{2}\end{array}$ \\
\hline $\begin{array}{c}\text { SD N 1 } \\
\text { PURWANEGARA }\end{array}$ & 37 & 36 & 89.71 & 3229.56 & 1.95 & 70.30 \\
\hline $\begin{array}{c}\text { SD N 2 } \\
\text { PURWANEGARA }\end{array}$ & 29 & 28 & 118.60 & 3320.80 & 2.07 & 58.07 \\
\hline $\begin{array}{c}\text { SD N 3 } \\
\text { PURWANEGARA }\end{array}$ & 24 & 23 & 112.32 & 2583.36 & 2.05 & 47.16 \\
\hline $\begin{array}{c}\text { SD N 4 } \\
\text { PURWANEGARA }\end{array}$ & 29 & 28 & 109.11 & 3055.08 & 2.04 & 57.06 \\
\hline SD N 1 BOBOSAN & 47 & 46 & 91.51 & 4209.46 & 1.96 & 90.23 \\
\hline
\end{tabular}




\begin{tabular}{ccccccc}
\hline SD N 2 BOBOSAN & 28 & 27 & 110.42 & 2981.34 & 2.04 & 55.16 \\
\hline SD N 3 BOBOSAN & 18 & 17 & 96.25 & 1636.25 & 1.98 & 33.72 \\
\hline SD MUHAMMADIYAH & 43 & 42 & 104.40 & 4384.80 & 2.02 & 84.79 \\
\hline $\begin{array}{c}\text { SD N 1 } \\
\text { BANCARKEMBAR }\end{array}$ & 34 & 33 & 104.73 & 3456.09 & 2.02 & 66.66 \\
\hline $\begin{array}{c}\text { SD N 3 } \\
\text { BANCARKEMBAR }\end{array}$ & 33 & 32 & 107.38 & 3436.16 & 2.03 & 64.99 \\
\hline $\begin{array}{c}\text { SD N 4 } \\
\text { BANCARKEMBAR }\end{array}$ & 25 & 24 & 108.08 & 2593.92 & 2.03 & 48.81 \\
\hline S & 347 & 336 & 1152.51 & 34886.82 & 22.21 & 676.95 \\
\hline
\end{tabular}

Hasil uji normalitas dan homogenitas menunjukkan semua sekolah memiliki kemampuan yang homogen sehingga semua sekolah dapat dijadikan sampel penelitian sebagai kelas eksperimen dan kontrol. Setelah melakukan pengacakan, terpilih kelas eksperimen SDN 2 Purwanegara, sedangkan SDN 1 Purwanegara sebagai kelas kontrol.

Variabel independentnya adalah pengembangan media teka-teki silang (TTS), sedangkan variabel dependentnya adalah pembelajaran tematik kelas VI SD. Instrumen yang digunakan dalam penelitian ini yaitu: (1) lembar validasi, (2) lembar angket/kuesioner, (3) lembar wawancara, dan (4) tes pengetahuan dengan bentuk soal pilihan ganda

Teknik pengumpulan data yang digunakan dalam penelitian ini menggunakan gabungan dari: angket, observasi, dan dokumentasi.

Penelitian ini menggunakan teknik analisis deskriptif kualitatif yang me-maparkan hasil pengembangan produk media pembelajaran tematik dan menguji tingkat kelayakan produk untuk di-implementasikan pada pembelajaran tematik di kelas.

Data yang diperoleh melalui instrumen penilaian pada saat uji coba dianalisis, dengan menggunakan statistik deskriptif kualitatif. Hasil analisis data digunakan sebagai dasar untuk merevisi produk media yang dikembangkan.

\section{PEMBAHASAN}

Berikut penulis paparkan tiap tahapan yang dilalui selama penelitian berlangsung.
Data mengenai pendapat atau tanggapan siswa dan guru yang terkumpul melalui angket dianalisis dengan statistik deskriptif.

\section{HASIL DAN PEMBAHASAN}

\section{HASIL}

Ada 3 hasil penelitian ini, yaitu tahap penyusunan dan pengembangan media TTS untuk pembelajaran tematik di kelas VI SD, mengetahui tingkat validitas media TTS pada pembelajaran tematik di kelas VI SD, dan mengetahui tingkat keefektifan media TTS pada pembelajaran tematik di kelas VI SD.

Tahap penyusunan dan pengembangan media TTS untuk pem-belajaran tematik di kelas VI SD ditempuh melalui 3 tahapan yaitu analisis kebutuhan guru terhadap penyusunan dan pe-ngembangan media TTS pada pem-belajaran tematik kelas VI SD, analisis kebutuhan siswa terhadap penyusunan dan pengembangan media TTS pada pembelajaran tematik kelas VI SD, dan pengembangan media TTS untuk pembelajaran tematik kelas VI SD. Hasil uji validasi dilakukan oleh pakar ahli materi dan pakar ahli media selaku validator ahli I dan validator ahli II serta oleh pengguna media TTS. Tingkat keefektifan media TTS dilakukan dengan uji coba pada kelas kecil dan uji coba kelas besar.

\section{Tahap Penyusunan dan Pe-ngembangan Media TTS untuk Pem-belajaran Tematik Kelas VI SD}


Peneliti melakukan observasi di kelas dengan mengamati secara langsung kondisi siswa dan guru dalam pembelajaran tematik di sekolah.

a. Hasil Analisis Kebutuhan Guru terhadap Penyusunan dan Pengembangan Media TTS untuk Pembelajaran Tematik Kelas VI SD

Pada tahap ini peneliti melakukan penyebaran angket kepada 5 orang guru kelas VI SD di Gugus Untung Suropati, Korwilcam Dindik Purwokerto Utara. Terdapat 24 pertanyaan yang harus dijawab oleh masingmasing guru kelas VI untuk mengetahui kebutuhan media pembelajaran tematik dengan TTS. Hasil analisis data angket per butir pertanyaan dijadikan sebagai pedoman dalam melakukan pengembangan media TTS.

b. Analisis Kebutuhan Siswa terhadap Penyusunan dan Pengembangan Media TTS untuk Pembelajaran Tematik Kelas VI SD

Pengisian data angket diberikan kepada 37 siswa SDN 1 Purwanegara kelas VI. Hasil angket ini untuk mengetahui kebutuhan siswa terhadap pengembangan media pembelajaran tematik permainan TTS. Hasil analisis data angket per butir pertanyaan dijadikan sebagai pedoman dalam melakukan pengembangan media TTS.

c. Pengembangan Media TTS untuk Pembelajaran Tematik Kelas VI SD.

Media pembelajaran tematik disusun, diteliti, dan dengan mengacu pada model 4D yang dikembangkan oleh S.Thiagarajan, Dorothy S. Semmel, dan Melvyn I.Semmel. Model 4D tersebut terdiri dari empat tahapan yaitu define (pendefinisian), design (perancangan), develop (pengembangan), dan dessiminate (penyebaran). Desain buku menggunakan aplikasi correl draw dengan ukuran kertas yang dipergunakan yaitu A4 $(14,8 \times 21 \mathrm{~cm})$, sebagai rancangan awal media TTS sebagai prototipe 1 .

Penggandaan produk media TTS untuk dapat dipergunakan sebagai media pembelajaran tematik di setiap Sekolah Dasar di Gugus Untung Suropati, Korwilcam Dindik Purwokerto Utara. Untuk kepentingan itu, peneliti bekerja sama dengan penerbit Satria Publisher sebagai tempat percetakannya berada di Jatilawang, Banyumas, Jawa Tengah.

\section{Hasil Uji Tingkat Validitas Media TTS pada Pembelajaran Tematik di Kelas VI SD.}

Hasil uji validasi dilakukan oleh para pakar ahli materi dan media sebagai validator ahli I dan II, serta oleh pengguna media TTS. Peneliti menyebar angket penggunaan Media TTS kepada 5 guru kelas VI di sekolah dasar tempat dilakukan ujicoba produk media, setelah divalidasi oleh pakar ahli.I dan II. Terdapat beberapa catatan koreksi serta masukan yang diberikan oleh kedua validator terhadap prototype 1 yang selanjutnya dijadikan bahan dasar untuk merevisi produk.

Hasil Validasi Ahli I tahap I dan II digambarkan dalam bentuk diagram 4.1 berikut ini.

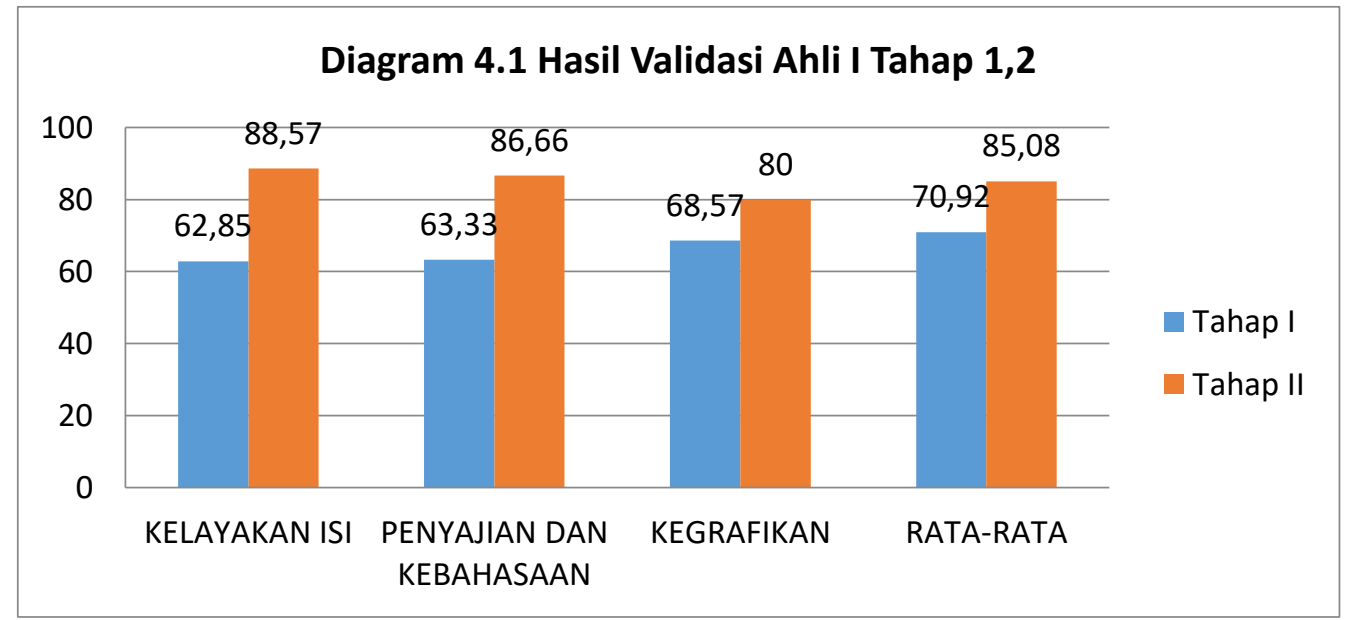


Berdasarkan diagram 4.1 di atas bahwa penilaian kelayakan media TTS oleh ahli I pada tahap I setelah dilakukan perbaikan selanjutnya di tahap II, rata- rata dari setiap aspek penilaian yang terdiri dari kelayakan isi, penyajian dan kebahasaan, serta kegrafikan memiliki kriteria "layak" yaitu $66 \leq \mathrm{x} \leq 100$. Setelah melakukan dua kali validasi kepada ahli I menyatakan media TTS Berkarakter sudah dapat digunakan.

Berikut ini adalah analisis hasil validasi ahli II yang telah dilakukan pada tahap Idan II. Hasil Validasi Ahli II tahap I dan II digambarkan dalam bentuk diagram 4.2 berikut ini.

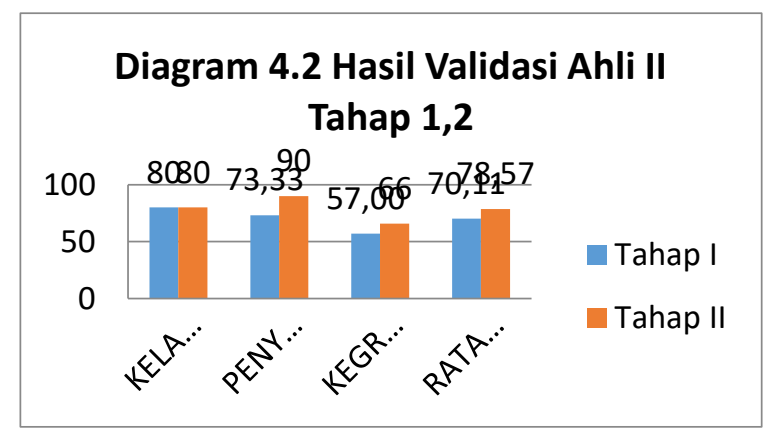

Berdasarkan diagram 4.2 di atas bahwa penilaian kelayakan media TTS oleh ahli II pada tahap I setelah dilakukan perbaikan selanjutnya di tahap II, rata- rata dari setiap aspek penilaian yang terdiri dari kelayakan isi, penyajian dan kebahasaan, serta kegrafikan memiliki kriteria "layak" yaitu 66 $\leq \mathrm{x} \leq 100$. Setelah melakukan dua kali validasi kepada ahli II menyatakan media TTS sudah dapat digunakan.

Berikut data hasil angket guru terhadap penggunaan media TTS dalam bentuk diagram 4.3.

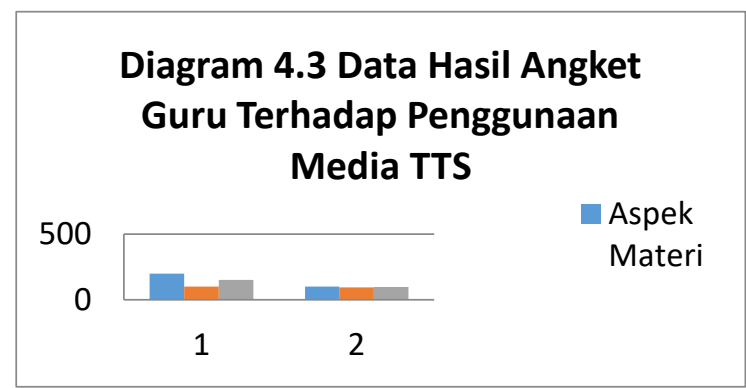

Berdasar diagram 4.3 diatas bahwa terdapat 2 aspek penilaian dalam angket tersebut yaitu aspek materi memperoleh prosentase $100 \%$ dan aspek motivasi/moral memperoleh $93 \%$, sehingga rata-rata perolehan skor 150 dengan rata-rata prosentase 96,5\% atau dengan kategori sangat layak.

Dari hasil penilaian validasi ahli materi dan ahli media serta hasil angket dari pengguna media TTS maka media TTS dapat dan layak digunakan sebagai media pembelajaran tematik di kelas VI SD.

\section{Hasil Uji Efektifitas Media TTS pada Pembelajaran Tematik di kelas VI SD}

Untuk mengetahui keefektifan media TTS dalam pembelajaran tematik di kelas VI SD maka dilaksanakan uji coba, antara lain sebagai berikut.

\section{a. Uji Coba Skala Kecil}

Pelaksanaan uji coba kelompok kecil dilakukan di SD N 1 Purwanegara pada tanggal 3 Mei 2021 dengan jumlah peserta didik 15 peserta didik. Peserta didik mengamati media yang diberikan dalam bentuk TTS, selanjutnya peserta didik diajak untuk mencoba mempraktikkannya secara langsung.

Berikut adalah gambar penjelasan peneliti kepada peserta didik tentang mekanisme penggunaan media TTS melalui guru kelasnya.

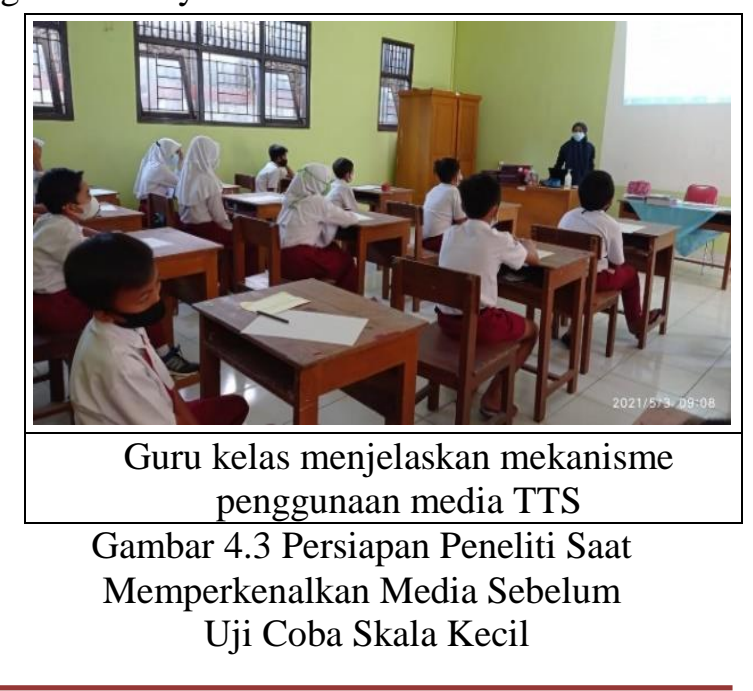


Peserta didik langsung mencoba menggunakan media TTS untuk memancing penguasaan kosakata yang dimiliki sesuai arahan dari peneliti. Berikut gambar peserta didik yang sedang melakukan uji coba penggunaan media.

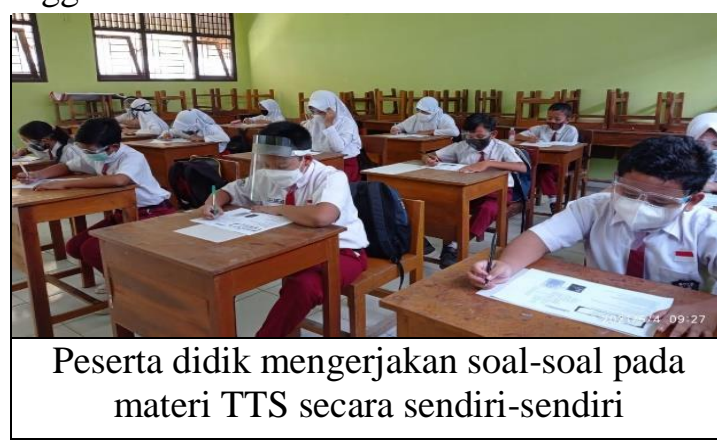

Gambar 4.4 Pelaksanaan Uji Coba Skala Kecil Setelah dilakukan uji coba dengan media TTS, peneliti melakukan penilaian. Peserta didik mengerjakan uji kompetensi berupa soal pilihan ganda dengan jumlah soal 30 nomer. Berikut ini hasil analisis uji kompetensi 15 peserta didik yang dijadikan uji coba kelas kecil. Setelah guru melakukan pembelajaran tematik dengan media TTS, diperoleh hasil nilai teredah 40 , nilai tertinggi 100 , serta rata- rata nilai 73,87

Peserta didik mengisi angket tanggapan terhadap produk pengembangan berupa media TTS berisi 12 pertanyaan dengan nilai maksimal tiap pertanyaan adalah 5 dan nilai minimal adalah 1 . Berikut ini adalah hasil angket tanggapan kelas kecil terhadap media TTS digambarkan dalam bentuk diagram 4.5 sebagai berikut ini.

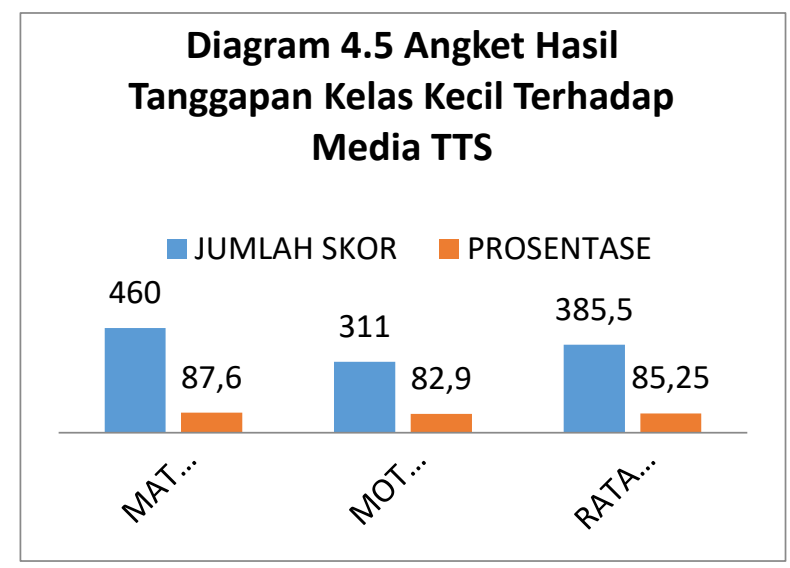

Berdasarkan diagram 4.5 di atas bahwa hasil angket tanggapan kelas kecil terhadap media TTS menunjukkan respon siswa terhadap aspek materi mendapat skor 460 , dengan perolehan prosentase $87,6 \%$ atau dikategorikan "sangat baik". Sedangkan respon siswa terhadap aspek motivasi/ moral mendapat skor 311, dengan perolehan prosentase $82,9 \%$ atau dikategorikan "sangat baik". Rata-rata perolehan skor kedua aspek (materi dan motivasi/moral) yaitu $(460+311)$ : $2=385,5$, sedangkan rata-rata perolehan prosentase kedua aspek tersebut yaitu $(87,6 \%$ $+82,9 \%): 2=85,25 \%$ atau dikategorikan "sangat baik"

\section{b. Pelaksanaan Uji Coba Skala Besar}

Uji coba instrumen dilakukan di SDN 1 dan 2 Purwanegara dengan kelas eksperimen SDN 2 Purwanegara dan kelas kontrol SDN 1 Purwanegara pada hari Senin, 10 Mei 2021. Kelas yang digunakan dalam pengujian instrumen ini adalah di kelas eksperimen dengan jumlah 29 peserta didik sedangkan kelas kontrol dengan jumlah 37 peserta didik. Bentuk tes yang diberikan adalah soal pilihan ganda 30 butir dengan alokasi waktu 45 menit.

Hasil belajar peserta didik diperoleh dari nilai evaluasi (posttest) dengan butir soal pilihan ganda dengan media TTS sebagai bentuk perlakuan khusus pada kelas eksperimen, sedangkan pada kelas kontrol menggunakan media belajar biasa dengan model pembelajaran konvensional. Berikut ini penulis paparkan hasil evaluasi dalam tabel 4.11.

Tabel 4.11 Hasil Evaluasi Uji Coba Kelas Eksperimen dan Kontrol

\begin{tabular}{lcc}
\hline \multicolumn{1}{c}{ Komponen } & X.1 & X. 2 \\
\hline N siswa & 29 & 37 \\
Nilai terendah & 63 & 57 \\
Nilai tertinggi & 97 & 87 \\
Jumlah Nilai & 2363 & 2700 \\
Rata-rata & 81 & 72.97 \\
\hline
\end{tabular}


Data pada tabel 4.11 digambarkan dalam bentuk grafik 4.6 berikut ini.

\section{Diagram 4.6. Hasil Evaluasi Uji Coba Kelas Eksperimen dan Kelas Kontrol}

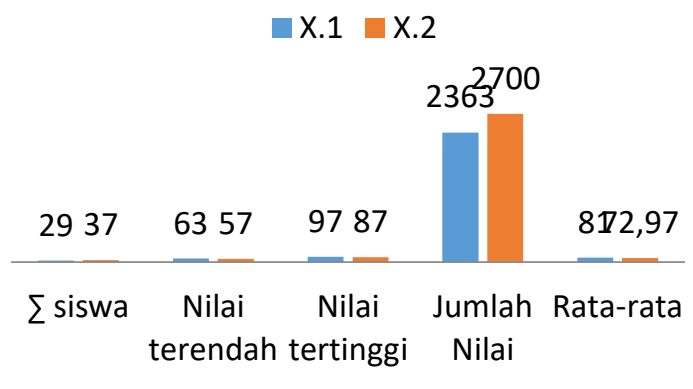

Berdasarkan diagram 4.6 di atas menunjukkan bahwa hasil evaluasi uji coba produk pada kelas eksperimen (X.1) dari jumlah 29 siswa, memperoleh nilai terendah 63, nilai tertinggi 97, jumlah nilai 2363, serta rata-rata nilai kelas 81 . Sedangkan pada kelas control (X.2) dari jumlah 37 siswa, memperoleh nilai terendah 57 , nilai tertinggi 87 , jumlah nilai 2700 , serta rata-rata nilai kelas 72,97 .

Hasil belajar peserta didik secara individu telah mencapai hasil belajar yang optimal dengan rata-rata nilai pada kelas eksperimen, yaitu 81. Pada kelas kontrol ada beberapa peserta didik yang belum tuntas belajar. Kelas X.1 atau kelas eksperimen dengan nilai tertinggi 97 dan terendah 63, sedangkan pada kelas kontrol dengan nilai tertinggi 87 dan terendah 57. Hal tersebut menunjukkan bahwa media TTS yang diterapkan pada kelas eksperimen mampu memengaruhi hasil yang baik terhadap hasil belajar peserta didik.

Selanjutnya untuk menguji pengaruh penggunaan media TTS terhadap kelas eksperimen, dilakukan uji $\mathrm{t}$ dengan membandingkan hasil belajar kelas eksperimen dengan kelas kontrol. Seperti yang sudah dijelaskan sebelumnya, pada kelas kontrol tidak dilakukan perlakuan khusus atau hanya menggunakan pembelajaran konvensional dengan sumber belajar buku paket saja. Berikut ini penulis paparkan hasil uji t tersebut dalam tabel 4.12.

Tabel 4.12 Hasil Uji t Penggunaan Media TTS

\begin{tabular}{|c|c|c|}
\hline Sumber variasi & Kelas Eksperimen & Kontrol \\
\hline Jumlah & 2363 & 2700 \\
\hline$n$ & 29 & 37 \\
\hline $\bar{x}$ & 81.00 & 72.97 \\
\hline Varians $\left(\mathrm{s}^{2}\right)$ & 109.47 & 81.25 \\
\hline Standart deviasi $(\mathrm{s})$ & 10.46 & 9.01 \\
\hline
\end{tabular}

Setelah dilakukan uji coba pada kelas besar, penulis juga mengumpulkan data angket untuk mengetahui respon peserta didik terhadap media TTS yang dikembangkan oleh penulis. Hasil angket diigambarkan pada diagram 4.7 berikut ini.

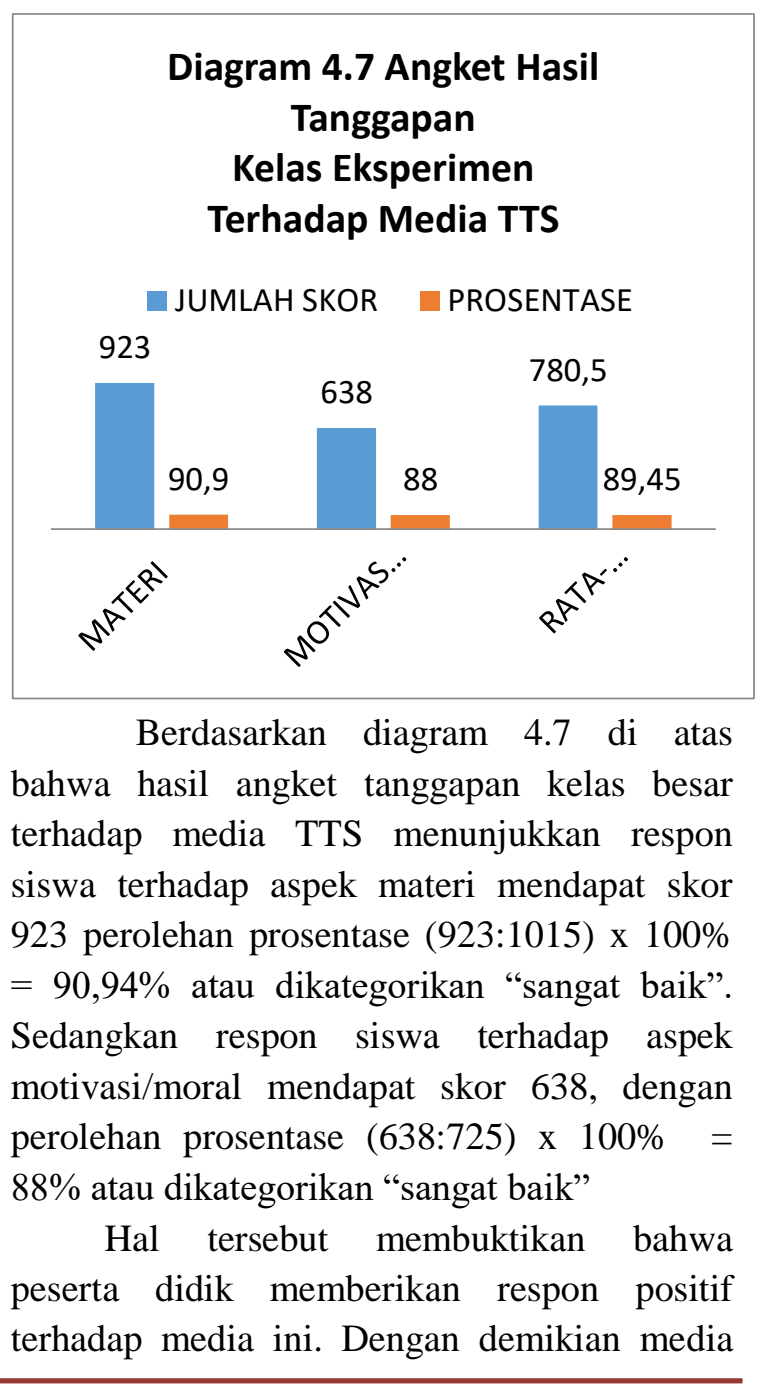


TTS layak digunakan dalam pembelajaran tema 9 kelas VI. Ada sebagian peserta didik yang kurang puas dengan media yang penulis susun. Hal tersebut dijadikan pertimbangan untuk penyempurnaan produk media TTS berikutnya.

\section{KESIMPULAN}

Berdasarkan rumusan masalah serta analisis data penelitian dan pembahasan, dapat disimpulkan :

1. Tahap penyusunan dan pengembangan media TTS ditempuh melalui 3 tahapan, yaitu menganalisis kebutuhan guru terhadap media TTS, menganalisis kebutuhan siswa terhadap media TTS, dan mengembangkan media TTS sebagai media pembelajaran tematik di kelas VI SD .

2. Validitas media TTS dinyatakan valid melalui penilaian dari hasil validasi ahli materi (I) dan ahli media (II), saran dan masukan yang baik untuk dikembangkannya produk media, serta penilaian dari pengguna media TTS. Dari hasil analisis validator ahli diperoleh rata-rata presentase berturut-turut sebesar $78 \%$ dan $74,34 \%$, dalam kategori sangat baik dan layak digunakan dalam kegiatan pembelajaran tematik kelas VI SD.

3. Tingkat keefektifan media TTS pada pembelajaran tematik dapat diketahui dari hasil uji coba produk yang menunjukkan bahwa hasil belajar pada kelas eksperimen yang menggunakan media TTS pada materi tema 9 pembelajaran tematik lebih baik daripada kelas kontrol yang menggunakan pembelajaran konvensional (buku teks). Media TTS juga mendapat respon baik oleh peserta didik.

\section{DAFTAR PUSTAKA}

Anitah, Sri . 2010. Media Pembelajaran. Surakarta : Yuma Pustaka.

Arikunto, Suharsimi. 1997. Dasar-dasar Evaluasi Pendidikan. Jakarta: Bumi Aksara.

Aziez, Furqanul dan Feisal Aziez. 2019. Kosa Kata Teori, Pengajaran, dan Pengukurannya.Purwokerto: UM Purwokerto Press.

Aziez,Furqanul, dkk. 2020. Ensiklopedia Pendidikan Indonesia. Depok: PT Rajagrafindo Persada.

Elviza,Yulia dkk.[2013]. Peningkatan Penguasaan Kosa Kata melalui Teknik Permainan Teka-Teki Silang di Kelas VII.A SMPN 2 Sungai Penuh.Jurnal Pendidikan Bahasa dan Sastra Indonesia, Jurnal Pendidika Bahasa dan Sastra Indonesia, Vol 1 no 2 ,Maret 2013.Seri F 399 - 476.

Hidayati, Nia. Artikel November 13, 2009 at 12:31 http://niahidayati. net/manfaatteka-teki-silang-sebagai-penambahwawasan- dan-mengasahkemampuan.html.

Iskandarwassid, Dadang S. 2008. Strategi Pembelajaran Bahasa. Bandung: PT.Remaja Rosdakarya.

Karitas Diana, dkk. 2018. Pegangan Guru Tema 9. Menjelajah Angkasa Luar. Buku Tematik Terpadu Kurikulum 2013. Buku Guru SD Kelas VI. Jakarta: Kemendikbud

Keraf, Gorys. 1991. Diksi dan Gaya Bahasa. Jakarta: Gramedia Pustaka Utama.

Majid, Abdul. 2014. Pembelajaran Te-matik Terpadu. Bandung: PT. Remaja Rosdakarya.

Mukrimaa, Syifa S.. 2014. 53 Metode Belajar Pembelajaran. Bandung: Universitas Pendidikan Indonesia.

Niken, Raeh. 2016. https://raehniken. blogspot.com/2016/12/hakikat- 
permainan.html, diunduh tanggal 241-2020 pukul 20.18 .

Permendikbud Nomor 22 Tahun 2006 tentang Standar Isi

Permendikbud Nomor 23 Tahun 2015 tentang Penumbuhan Budi Pekerti

Rahmarizqy. 2017. Gerakan Literasi Sekolah, https://rahmarizqy. Word press.com /2017/02/02/gerakan-literasi-

sekolah/diunduh tanggal 7-9-2020 pukul 11.00

Rizki Fajar, dkk. 2020. Tema 9. Menjelajah Angkasa Luar. Yogyakarta: PT. Penerbit Intan Pariwara

Setyosari, Punaji. 2012. Metode Penelitian Pendidikan dan Pengembangan. Jakarta: Kencana Prenada Media Group.

Sofiatin. 2015. Hubungan Penguasaan Kosa Kata dan Penguasaan Kalimat Efektif dengan Keterampilan Menulis Esai Siswa. Jurnal Lingua, Vol 1 nomor 2.

Sudjana, Nana dan Ahmad Rivai. 2010. Media Pengajaran.Bandung: Sinar Baru Algensindo.

Sugiyono. 2015. Metode Penelitian Kuantitatif, Kualitatif, dan $R \& D$. Bandung: Alfabeta Bandung.

Sukirno. 2016. Belajar Cepat Menulis Kreatif Berbasis Kuantum. Yogyakarta; Pustaka Pelajar.

Susilana Rudi, dkk. 2008. Media Pembelajaran.Bandung: $\quad$ CV.Wacana Prima.

Suyatno. 2005. Permainan Pendukung Pembelajaran Bahasa dan Sastra. Jakarta: Grasindo.

Ul Husna, Gusmita dan Hastuti, Hera. 2019. Pengembangan Media Teka - Teki Silang sebagai Media Pembelajaran Sejarah di Kelas XI SMA. Jurnal Halaqah,Vol 1 no 4,Page 402-411,
ISSN [online] 2685-6379, Oktober 2019.

Ulfayanti,Nur. 2017. Skripsi. Pengembangan Media Permainan Teka-Teki Silang pada Mata Pelajaran Biologi Kelas XI di SMA Negeri 12 Makasar. November 2017.

Wasgito, Andi. 2014. Pengembangan Media Permainan Edukatif Teka-Teki Silang [TTS] dalam .Proses Pembelajaran Siswa Kelas VII SMP Negeri 2 Kalianget. Jurnal Seni Rupa,Vol 2 no 3.

http://puzzlemaker.discoveryeducation.com/Cr issCrossSetupForm.asp,. diunduh tanggal 24-1-2020 pukul 20.18. 